\title{
NEW RECORDS OF THE CRAMBID MOTH EUCLASTA SPLENDIDALIS (HERRICH- SCHÄFFER, [1848]) (LEPIDOPTERA: CRAMBIDAE) IN CROATIA WITH NOTES ON PYRALOIDEA FAUNA FROM THE NERETVA VALLEY
}

\author{
Danijela Gumhalter ${ }^{1}$, Mladen Kučinić', Mladen Vajdić, \\ ${ }^{\dagger}$ Franjo Perović ${ }^{3}$, Dragan Pelić Fixa ${ }^{4}$ \& Gordan Lukač ${ }^{5}$
}

\author{
${ }^{1}$ Azuritweg 2, D-70619 Stuttgart, Germany (e-mail: danijela.gumhalter@gmail.com) \\ ${ }^{2}$ Department of Biology, Faculty of Science, University of Zagreb, Rooseveltov trg 6, \\ HR-10000 Zagreb, Croatia \\ ${ }^{3}$ Croatian Natural History Museum, Demetrova 1, HR-10000 Zagreb, Croatia \\ ${ }^{4}$ Nikole Cara 7, HR-51260 Crikvenica, Croatia \\ ${ }^{5} J U$ NP Paklenica, Dr. F. Tuđmana 14a, HR-23244 Starigrad-Paklenica, Croatia
}

\begin{abstract}
Gumhalter, D., Kučinić, M., Vajdić, M., Perović, F., Pelić Fixa, D. \& Lukač, G.: New records of the crambid moth Euclasta splendidalis (Herrich-Schäffer, [1848]) (Lepidoptera: Crambidae) in Croatia with notes on Pyraloidea fauna from the Neretva Valley. Nat. Croat., Vol. 27, No. 1, 225-232, 2018,

In the following paper, new information about the occurrence of the pyraloid moth Euclasta splendidalis (Herrich-Schäffer, [1848]) in Croatia is presented. Although this species from the microlepidopterous family Crambidae was presented as a new one in the Croatian fauna in 2012, three specimens were discovered during an examination of a large number of pyraloid moths collected by Mladen Kučinić in the 1990s. These specimens of Euclasta splendidalis were collected during several field trips to the Neretva Valley, south Dalmatia, in August 1996 and 1997 and are the oldest findings of Euclasta splendidalis in Croatia. Also, two specimens were collected during a field investigation in the same area conducted in 2016.
\end{abstract} Zagreb.

These additional records suggest that this local and rare species has been present in the fauna of Croatia for quite a long time and that it has become permanently present in the fauna of Croatia. They also deepen the knowledge on the distribution of this species within the same area. Furthermore, a list of additionally recorded pyraloid species from the valley of the Neretva River is given.

Key words: Microlepidoptera, Pyraloidea, Euclasta splendidalis, Neretva Valley, Dalmatia

Gumhalter, D. \& Kučinić, M., Vajdić, M., Perović, F., Pelić Fixa, D. \& Lukač, G.: Novi nalazi livadnog moljca Euclasta splendidalis (Herrich-Schäffer, [1848]) (Lepidoptera: Crambidae) u Hrvatskoj s osvrtom na faunu Pyraloidea iz doline Neretve. Nat. Croat., Vol. 27, No. 1, 225-232, 2018, Zagreb.

U radu iznosimo podatake o novim nalazima vrste livadnog moljca Euclasta splendidalis (HerrichSchäffer, [1848]) u Hrvatskoj. Iako je ova vrsta mikrolepidoptera iz porodice Crambidae 2012. godine zabilježena kao nova vrsta za faunu Hrvatske, tri su primjerka pronađena pregledavajući zbirku Pyraloidea dr. sc. Mladena Kučinića prikupljenih tijekom 1990-tih godina. Primjerci vrste Euclasta splendidalis su prikupljeni tijekom terenskih istraživanja u dolini Neretve, u južnoj Dalmaciii, u kolovozu 1996. i 1997. godine. Ovi nalazi predstavljaju najstarije nalaze ove vrste s područja Republike Hrvatske. Usto, dva su primjerka ulovljena tijekom terenskih istraživanja koja su izvršena 2016. godine u dolini Neretve. 
Ovi dodatni nalazi ukazuju na to da je ta lokalna i rijetka vrsta duže prisutna u fauni Hrvatske, te da je postala stalni element hrvatske faune. Ovi nalazi također proširuju znanje o distribuciji vrste Euclasta splendidalis na istome području. Nadalje se u radu daje popis dodatnih vrsta Pyraloidea zabilježenih na području doline Neretve.

Ključne riječi: Microlepidoptera, Pyraloidea, Euclasta splendidalis, dolina Neretve, Dalmacija

\section{INTRODUCTION}

The superfamily Pyraloidea is the third largest within the Lepidoptera, following Noctuoidea and Geometroidea. It is composed of two families - Pyralidae and Crambidae. The family Crambidae, to which the genus Euclasta Lederer, 1855 belongs, currently includes 9,655 described species (van NieuKERKEN et al., 2011). According to the Fauna Europaea Website (Nuss et al., 2011) only two species from this genus are present in Europe: Euclasta splendidalis (Herrich-Schäffer, [1848]) distributed in the eastern parts of Europe and Euclasta varii Popescu-Gorj \& Constantinescu, 1973, known only from Spain and the Balearic Islands (Ylla et al., 2008; Pérez De-Gregorio \& Requena Miret, 2008), and Malta (Sammut, 2005). Outside of Europe Euclasta varii is widespread on the African continent and in the state of Yemen (SLAmKa, 2013).

Although there is a long tradition of lepidopterological investigation in Croatia, there is still no list of pyraloid moth species for the country. In the past, faunistic studies were conducted only sporadically and did not always cover the microlepidopterous families, and in that case, they covered only specific regions of the country (e.g. MAnN, 1867; Rebel, 1889, 1895, 1904; Abafi-Aigner et al., 1896; Stauder, 1932, 1933). Since no systematic research of Microlepidoptera has been conducted, the fauna of pyraloid moths in Croatia is quite unknown.

Euclasta splendidalis is very local on xeric habitats in Southeast Europe (SLAmKA, 2013) and a rather rare species. In Croatia it was so far only recorded in the valley of the Neretva River. Although this area is under a strong anthropogenic impact, specific ecological features and vegetation characteristics do probably occur.

The aims of this paper are to give new localities of the local and rare species Euclasta splendidalis in Croatia and to present a list of pyraloid moth species also occurring in the area of the Neretva Valley.

\section{MATERIALS AND METHODS}

The second author conducted several field investigations and collected about 600 specimens of pyraloid moths in different localities in South Croatia (Nature Park Biokovo, National Park Mljet, Neretva Valley etc.). All Pyraloidea species were caught with a UV light and the collected specimens were deposited in his collection in the Croatian Natural History Museum in Zagreb (coll. Lepidoptera Kučinić). Here presented specimens originate from the project "Investigation of the entomofauna in the area of the lower course of the Neretva River" which was carried out in the years 1996 and 1997. This project was organized by the Croatian Natural History Museum in Zagreb and the Faculty of Science, University in Zagreb. The results of this research were never published.

In order to give a species list from the Neretva Valley, other Pyraloidea species from the Lepidoptera collection were also identified. 
The determination of all species was conducted according to SLAMKA (2013) and the systematic presentation follows Fauna Europaea. The biological features and distribution of the species Euclasta splendidalis was provided by Koren (2012) and SLAmKA (2013).

\section{RESULTS AND DISCUSSION}

While this Lepidoptera collection was being analysed, three specimens of Euclasta splendidalis were identified (Fig. 1). In addition to the findings from the Lepidoptera collection, this particular species was also recorded in the same area of Croatia, as part of the faunistic investigation of Pyralidae and Crambidae, conducted by the first author of this paper. All specimens were collected from the Neretva Valley (Fig. 2), the area where it was found almost 15 years later by Konen (2012). In order to give a more detailed overview of the species' distribution in the Neretva Valley those records were aggregated with those from Koren (2012).
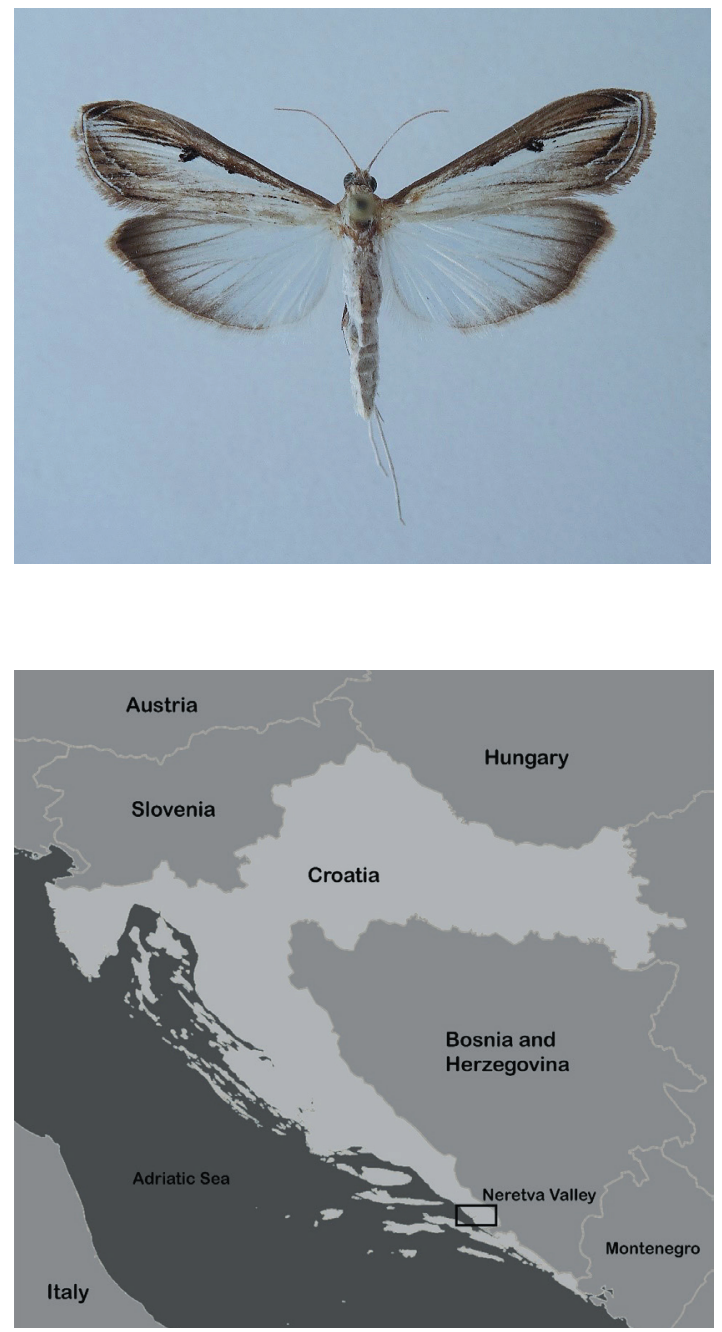

Fig. 1. Adult of Euclasta splendidalis recorded in 2016 in Croatia. (Photo: D. Gumhalter)

Fig. 2. Map showing the position of the surveyed area. 
A chronologically ordered overview of all records is given below (Fig. 3):

1. Bijeli Vir; bank of Mislina River; 5.VIII.1996 (1 specimen, leg. G. Lukač);

2. Obli Vir- Pižinovac; no coordinates available; 13.VIII.1996 (1 specimen, leg. Mladen Kučinić \& Dragan Pelić Fixa);

3. Soline; grassland next to Neretva River; no coordinates available; 11.VIII.1997 (1 specimen, leg. Mladen Kučinić);

4. Kamp Rio, Opuzen; karstic slopes on one side and swampy boggy grassland and marshland on the other; 43.014925, 17.468594; 6.VIII.2012 (3 specimens, leg. Toni Koren) (Koren, 2012);

5. 500 metres south of Rogotin; karstic slopes on one side and swampy boggy grassland and marshland on the other; 43.039913, 17.476838; 7.VIII.2012 (3 specimens, leg. Toni Koren) (Koren, 2012);

6. Pižinovac; watered, cultivated slots and wetlands on one side and karstic slopes on the other side (Fig. 4); 42.983337, 17.543993; 4.IX.2016 (2 specimens, leg. Gumhalter).

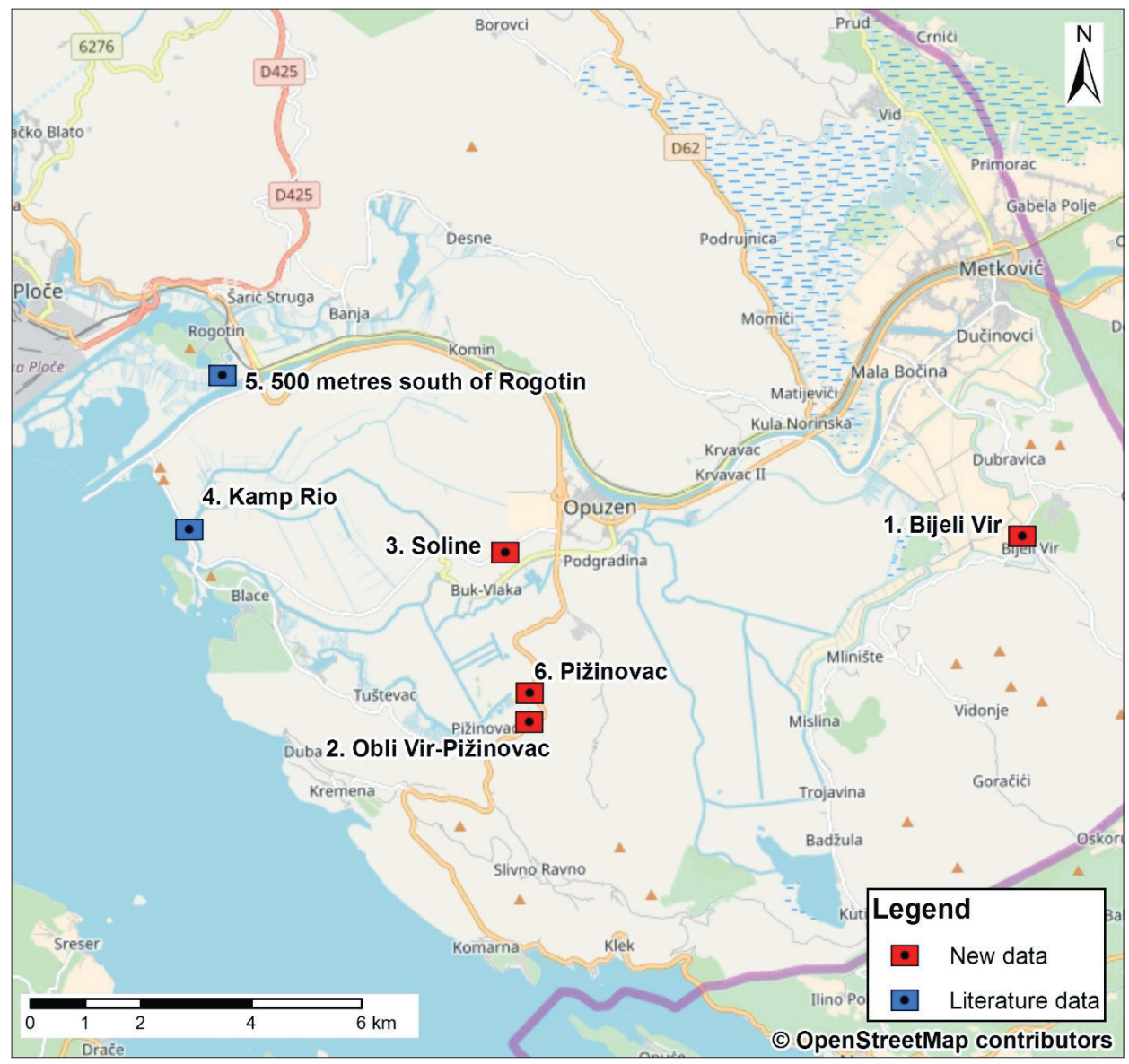

Fig. 3. Distribution of Euclasta splendidalis in the area of the lower course of the Neretva River. 


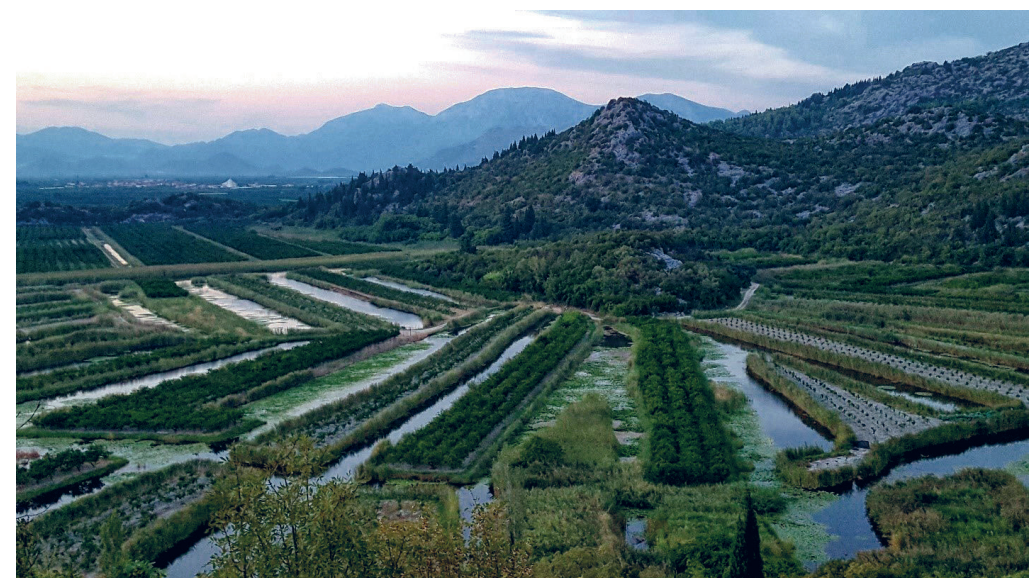

Fig. 4. Watered, cultivated slots and karstic slopes of Pižinovac, the location where Euclasta splendidalis was recorded in 2016. (Photo: D. Gumhalter)

Additionally, 40 pyraloid moth species were collected in the same area. All these findings originate from the second author's project in the Neretva Valley and the specimens are deposited in his Lepidoptera collection. Species marked with $\left(^{*}\right)$ were also collected during the first author's faunistic investigation of Pyralidae and Crambidae in the Neretva River Valley. Species marked with $\left(^{* *}\right)$ were recorded only from the first author's investigation.

Altogether, 42 moth species were collected from the area:

Cataclysta lemnata (Linnaeus, 1758)

Elophila nymphaeata (Linnaeus, 1758)

Nymphula nitidulata (Hufnagel, 1767)

Parapoynx stratiotata (Linnaeus, 1758)

Agriphila tolli (Bleszyński, 1952)

Agriphila tristella ([Denis \& Schiffermüller], 1775)*

Catoptria falsella ([Denis \& Schiffermüller], 1775)*

Catoptria pinella (Linnaeus, 1758)

Chilo phragmitella (Hübner, 1805)

Crambus lathoniellus (Zincken, 1817)

Pediasia contaminella (Hübner, 1796)

Xanthocrambus saxonellus (Zincken, 1821)

Anania verbascalis ([Denis \& Schiffermüller], 1775)

Ecpyrrhorrhoe diffusalis (Guenée, 1854)

Nascia cilialis (Hübner, 1796)

Pyrausta aurata (Scopoli, 1763)

Pyrausta castalis (Treitschke, 1829) ${ }^{* *}$

Pyrausta despicata (Scopoli, 1763)

Pyrausta purpuralis (Linnaeus, 1758)

Pyrausta sanguinalis (Linnaeus, 1767) 
Schoenobius gigantella ([Denis \& Schiffermüller], 1775)**

Eudonia mercurella (Linnaeus, 1758)

Dolicharthria punctalis ([Denis \& Schiffermüller], 1775)*

Metasia carnealis (Treitschke, 1829)

Nomophila noctuella ([Denis \& Schiffermüller], 1775)*

Palpita vitrealis (Rossi, 1794)

Pleuroptya balteata (Fabricius, 1798)

Pleuroptya ruralis (Scopoli, 1763)

Udea ferrugalis (Hübner, 1796)

Euchromius superbellus (Zeller, 1849)*

Lamoria anella ([Denis \& Schiffermüller], 1775)

Acrobasis obliqua (Zeller, 1847)

Acrobasis suavella (Zincken, 1818)

Acrobasis tumidana ([Denis \& Schiffermüller], 1775)

Homoeosoma sinuella (Fabricius, 1794)

Oncocera semirubella (Scopoli, 1763)

Oxybia transversella (Duponchel, 1836)

Pempelia palumbella ([Denis \& Schiffermüller], 1775)

Endotricha flammealis ([Denis \& Schiffermüller], 1775)*

Hypsopygia costalis (Fabricius, 1775)

Pyralis regalis ([Denis \& Schiffermüller], 1775)

Stemmatophora brunnealis (Treitschke, 1829)

A detailed faunistic analysis of Pyraloidea fauna in Croatia is not the aim of this study, and will be presented through a study on biodiversity and biogeograhical features of Pyralidae and Crambidae in Croatia, especially in the Mediterranean part of the country.

Euclasta splendidalis was first described from Turkey as Botys splendidalis by Herrich-Schäffer in 1848. Nuss et al. (2011) state that the species is present in Asia Minor, Turkmenistan, Azerbaijan and Cyprus. The species is local in Bulgaria, Romania, Macedonia (KLIMESCH, 1968) and Greece (Wüst, 1997). According to Slamka (2013), it was also recorded from Transcaucasia, Syria, Transcaspia and the north of Iran. In 2015, it was recorded in the south of Italy (ZiLLI \& PAvesi, 2015).

In Europe, the leaf feeding Euclasta splendidalis allegedly occurs only on the Mediterranean species Silk Vine or Greek Liana Periploca graeca from the family Asclepiadaceae (Popescu-GorJ, 1977; SzÉKely, 2006) and prefers xeric habitats (SzÉKely, 2006). It is bivoltine, flying from June to July and from August to September.

The species was recorded in 2012 in Croatia and these findings represent the westernmost distribution points of Euclasta splendidalis (Koren, 2012). However, this crambid species had actually been found almost 15 years earlier during faunistic research into the insect fauna of the Neretva Valley. Later in 2016 its occurrence was reconfirmed in the same area. All these findings indicate that Euclasta splendidalis is well established in the Croatian moth fauna. It has not been recorded elsewhere in the country, only in the lower course of the Neretva River. Therefore, the species has a small and restricted distribution area in Croatia. Moths are dependent on specific food plants, so obviously 
the vegetation composition influences their occurrence and distribution. Therefore, specific ecological features and vegetation characteristics must exist, in spite of the strong anthropogenic impact through intensive agricultural activities in that particular area. Not only the finding of Euclasta splendidalis (Lederer, 1861), but also the finding of other interesting species like Rhyaparoides metelkana from the subfamily Arctiinae of the family Erebidae are proof of this. The Neretva Valley is the only known location of this species in Croatia (Kučınić et al., 2014).

These findings provide more information on the expansion of the species occurrence in this small area, and indicate that Euclasta splendidalis is local and rare in Croatia. In the future, more faunal surveys should be conducted in order to expand the knowledge about its distribution, as well as biological or ecological research of the area. Euclasta splendidalis is obviously a permanent element of the fauna of this area and further research should be carried out in order to define possible measures for habitat and species protection.

Received June 1, 2018

\section{REFERENCES}

Abafi-Aigner, L., Pavel, J. \& Uhry, F., 1896: Fauna Regni Hungariae. Lepidoptera. Regia Societas Scientiarum Naturalium Hungarica, Budapest, $82 \mathrm{pp}$.

HerRICH-SchäFFER, G.A.W., 1847-1855: Systematische Bearbeitung der Schmetterlinge von Europa, zugleich als Text, Revision und Supplement zu Jakob Hübner's Sammlung europäischer Schmetterlinge. Vierter Band. Die Zünsler und Wickler, Regensburg, p. 32.

KočA, Gj., 1900. Prilog fauni leptira (Lepidoptera) Hrvatske i Slavonije. Glasnik Hrvatskog naravoslovnog društva 13(1-3), 1-67.

KLimesch, J., 1968: The Lepidoptera fauna of Macedonia, IV. Microlepidoptera. In Posebno izdanie. Prirodonaucen Muzej Skopje 5, 201 pp.

Koren, T., 2012: The western most record of Euclasta splendidalis (Herrich-Schäffer, 1884) (Lepidoptera: Crambidae) in Europe. Polish Journal of Entomology 81, 331-334.

Kučinić, M., Matešić, M., Koren, T., Mrnjavčić Vojvoda, A., Vajdić, M., Pelić Fixa, D., Bukvić, V. \& Perović, F., 2014: First check list of the subfamiliy Actiinae (Lepidoptera, Erebidae) in Croatia, with the finding of Rhyparioides metelkana (Lederer, 1861), new species in Croatian fauna from the valley of the Neretva river. Natura Croatica 23(1), 67-87.

ManN, J., 1867: Schmetterlinge gesammelt im Jahre 1866 um Josefsthal in der croat. Militaergrenze. Verhandlungen der Zoologisch-Botanischen Gesellschaft in Wien 17, 63-76.

Nuss, M., Landry, B., Mally, R., Vegliante, F., Tränkner, A., Bauer, F., Hayden, J., Segerer, A., Schouten, R., Li, H., Trofimova, T., Solis, M.A., De Prins, J. \& Speidel, W., 2003-2017: Global Information System on Pyraloidea. http://www.pyraloidea.org (accessed 11 April 2018).

Nuss, M., Speidel, W. \& Segerer, A., 2000-2013: Pyraloidea. In: Fauna Europaea Web Service. Version 2017.06, http://www.faunaeur.org. (accessed 18 April 2018).

Pérez De-Gregorio, J. J. \& Requena Miret, E., 2008: Microlepidòpters (Pyralidae, Crambidae) nous o interessants per la Fauna Catalana i Iberobalear (VIII) (Lepidoptera). Ses. Entom. ICHN-SCL 13-14 (2003-2007), 91-106.

Popescu-Gorj, A. \& Constantinescu, A., 1977: Revision of the genus Euclasta Lederer (Lepidoptera, Pyraustinae). A taxonomic and zoogeographic study. Travaux du Muséum d'Histoire Naturelle"Grigore Antipa", Bucuresti 18, 157-245.

ReBEL, H.,1889: Beiträge zur Microlepidopteren-Fauna Österreich-Ungarns. Verhandlungen der kaiserlich-königlichen zoologisch-botanischen Gesellschaft in Wien 39, 293-326.

Rebel, H., 1895: Verzeichniss der von Dr. R. Sturany im Jahre 1895 in Croatien gesammelten Lepidopteren. Verhandlungen der zologisch-botanischen Gesellschaft in Wien 45, 390-392.

Rebel, H., 1904: Studien über die Lepidopterenfauna der Balkanländer. II. Teil. Bosnien und Herzegowina. Annalen des Naturhistorischen Museums in Wien 19, 97-377. 
Sammut, P., 2005: The correct identity of three Pyralidae moths from the Maltese Islands (Lepidoptera: Pyralidae). SHILAP Revista de Lepidopterologia 33 (130), 235-238.

Stauder, H., 1932: Die Schmetterlings-fauna der illyroadriatischen Festland-und Inselzone (Faunula Illyro-Adriatica). Zeitschrift für wissenschaftliche Insektenbiologie Berlin 12, 53-54, 71-72, 92, 131-132, 150-152, 200, 233-234, 256.

StAuder, H., 1933: Die Schmetterlings-fauna der illyroadriatischen Festland-und Inselzone (Faunula Illyro-Adriatica). Zeitschrift für wissenschaftliche Insektenbiologie Berlin 13, 18-20.

Slamka, F., 2013: Pyraloidea of Europe (Lepidoptera) Volume 3, Pyraustinae \& Spilomelinae. František Slamka, Bratislava, $357 \mathrm{pp}$.

SzÉKely, L., 2006: Lepidopterele din delta Dunarii (The Butterflies and moths of the Danube Delta). Ed: Disz-Tipo. Sacele, $152 \mathrm{pp}$.

Van Nieukerken, E.J., Kaila, L. \& Kitching, 2011: Order Lepidoptera. Animal biodiversity: An outline of higher-level classification and survey of taxonomic richness. Zootaxa, 3148, 212-221.

Wüst, P., 1997: Euclasta splendidalis (Herrich-Schäffer, 1849), neu für die Fauna von Griechenland (Lepidoptera: Pyralidae: Pyraustinae) Entomologische Zeitschrift 107(8), 352-353

Ylla, J., Macià, R. \& Dionisıo, H.M., 2008: Piralídos y Cràmbidos detectados en Almería, España (Lepidoptera: Pyraloidea). SHILAP Revista de Lepidopterologia, Madrid 36(142), 191-204.

Zilli, A. \& Pavesi, F., 2015: New or little known Pyraloids from Italy (Lepidoptera: Pyraloidea). Phegea 43(3), 81-96. 